\section{Etiology of acute diarrhea in children attending the emergency service in Sergipe, Northeast-Brazil}

Ricardo Queiroz Gurgel, Flávia Apolônio Nóbrega, Ana Paula C. do Amaral Vicente, Victor Santana Santos, Julianne C. Vasconcelos de Santana, Isabel Ribeiro Lopes, Íkaro Daniel de Carvalho Barreto, Luciane M. Storti de Melo.

Graduate Programs of Health Sciences and of Parasitic Biology. Federal University of Sergipe (UFS), Aracaju, SE, Brazil

\section{Background}

Diarrhea still represents $8 \%$ of deaths in children under 5 years of age worldwide (1). This study aims to verify the presence of three etiological agents (Rotavirus, Norovirus and Cryptosporidium spp.) associated with acute gastroenteritis in children aged 0 to 11 years old in the reference Emergency Hospital of Sergipe, in Sergipe State, Northeast-Brazil.

\section{Methods}

An observational cross-sectional study was conducted in 92 children with acute diarrhea from January to July in 2014 .

\section{Results}

It was observed that $57(62 \%)$ of the samples presented infection by one of the pathogens studied. The average age of the children affected by one of the three pathogens was 22.24 months $(95 \% \mathrm{Cl}, 15.26-29.21), 64 \%$ of males and $36 \%$ of females. In addition, $3 \%$ (2) presented co-infection by Norovirus and Cryptosporidum spp.. Rotavirus and Norovirus were present in all months of the studied period, but Cryptosporidium spp. was only observed in two months (April and May) during the fall.
In relation to the vaccination against Rotavirus of those infected by one of the three pathogens, $66 \%(n=38)$ received the two doses, $5 \%(n=3)$ were not vaccinated and $29 \%(n=17)$ could not inform.

\section{Conclusions}

The presence of the three pathogens was verified in a reference emergency pediatric center, with Norovirus currently being the most frequent agent (49\%), followed by Rotavirus (10\%) and Cryptosporidium spp. (4\%).
Table 1. Frequency of the etiological agents Studied.

\begin{tabular}{|c|c|c|}
\hline $\begin{array}{c}\text { Intestinal } \\
\text { pathogens }\end{array}$ & (n) & $\%$ \\
\hline Norovírus & 46 & 49 \\
\hline Rotavírus & 9 & 10 \\
\hline $\begin{array}{c}\text { Cryptosporidium } \\
\text { spp. }\end{array}$ & 4 & 4 \\
\hline Not identified & 35 & 37 \\
\hline Total & 94 & $100 \%$ \\
\hline
\end{tabular}

Picture 1: Monthly distribution of infections among 57 children.

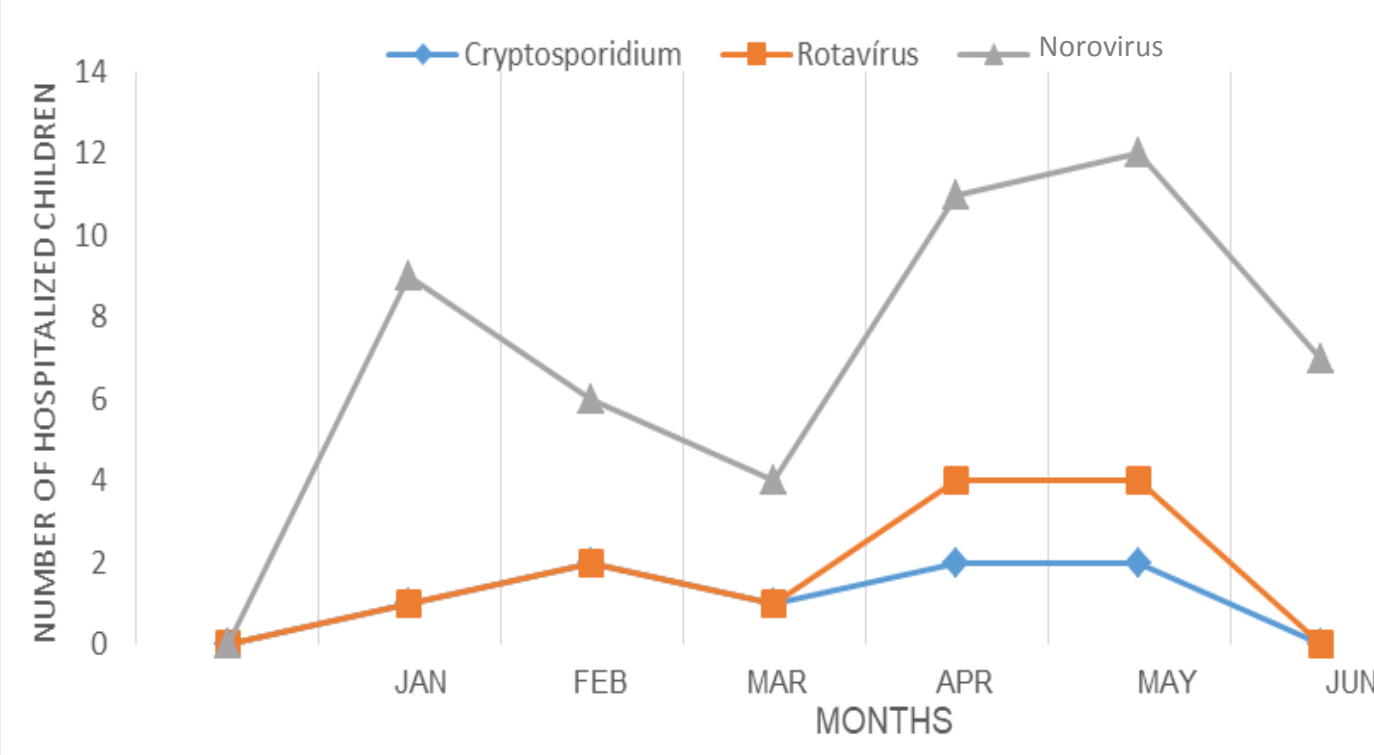

